\title{
SURFACE MODIFICATION OF POLYMER NANOCOMPOSITES BY GLOW DISCHARGE PLASMA TREATMENT
}

\author{
AGRAWAL N. K. ${ }^{1}$, AGARWAL R. ${ }^{2}$, GAUTAM A. $K .{ }^{2}, \operatorname{VIJAY} Y . K .{ }^{3}$, SWAMI K. $C .{ }^{1}$ \\ ${ }^{1}$ Department of Physics, Malaviya National Institute of Technology, Jaipur, Rajasthan, India; \\ ${ }^{2}$ Centre for Converging Technologies, University of Rajasthan, Jaipur, Rajasthan, India; \\ ${ }^{3}$ Department of Physics, University of Rajasthan, Jaipur, Rajasthan, India \\ ${ }^{3}$ Vivekananda Global University, V I T Campus, Jaipur, Rajasthan, India
}

Systematic study was carried out to characterize the effects of Argon ion plasma on nanocomposite polymer membrane. Nanoparticles of cobalt (Co) are synthesized by chemical root. 20 micron nanocomposite polymeric membranes were prepared using solution casting and spin coating method. Argon ion plasma treatment was done for these membranes. These membranes were characterized before and after plasma treatment to make comparative study by different technique such as optical microscopy, SEM-scanning electron microscope, Fourier transform infrared spectroscopy. Results show that plasma treatment is a quite effective tool for improving surface and chemical properties of composite membranes with unique characteristics.

Keywords: polymer nanocomposites, synthetic membrane, plasma treatment, ion energy, plasma etching.

Metallic nanoparticles are traditionally synthesized by wet chemical synthesis where the chemicals used are often toxic [1-3]. Since metal nanoparticles are widely used in biological applications [4] there is a growing need to develop environmentally friendly processes for nanoparticle synthesis that do not leave the toxic by-products [5-6]. Biological methods of nanoparticle synthesis using micro-organisms, plants including algae, fungi, bryophyte, pteridophyta etc. have been suggested as possible ecofriendly alternatives to chemical and physical methods [7-8]. Among the various transition metal nanoparticles, cobalt (Co) nanoparticles have recently received substantial attention for various reasons - likehigh refractive index [9], high electrical conductivity [10], chemical catalysis [11] and antimicrobial activities [12].

Polymers have become very important materials in modern manufacturing processes due to a wide variety of chemical properties [13-14], but it is well known that permanent bonding [15], printing [16], coating [17], etc. are difficult on many polymers without surface pre-treatment [18]. Therefore, after-surface treatment of modified polymers has significant advantages in specific requirements of surface properties while retaining the bulk properties unchanged [19-21]. Physical and chemical modifications of polymeric materials are also of great interest in artificial skin development and other biomedical applications [22].

The complex nature of plasma due to presence of ions, neutrals and radiation in discharge makes low-temperature plasmas widely useable in a growing number of materials fabrication processes including etching of complex patterns and surface modifications of polymeric membranes [23]. Plasma surface treatment usually refers to plasma reaction that either results in modification of the molecular structure of the surface or atomic substitution [24]. The accelerated electrons from the plasma have suf-

Corresponding author. N. K. AGRAWAL, e-mail: research.nka@gmail.com 
ficient energy to induce cleavage of the chemical bonds in membrane structure and to form macromolecule radicals, which subsequently initiate graft copolymerization [25]. Plasma treatment can be done by either regular plasma treatment, or plasma graft copolymerization (PGC) [26].

Various plasma components such as electrons, ions, radical etc. are involved in this process. These components react on exposed surfaces. Since some parts of the surface are exposed to energies higher than the characteristic bond energy of polymers, these parts undergo scission reactions and form new bonding configurations on the surface [27]. Plasma treatment of polymer surface causes not only a modification during the plasma exposure, but also leaves active sites on the surfaces which are subjected to post-reaction [28]. Glow-discharge plasma technique is particularly useful for functionalization of surfaces as it is possible to modify outermost surface layer by this technique $[15,29]$. These factors improve the adhesion properties of the surface [30].

In this paper we have synthesized polymer nanocomposites using Co NPs and Poly Methyl Meth Acrylate (PMMA). These materials were exposed to Ar plasma, and modification in the surface and chemical properties was investigated.

Materials and methods. In the present study Co NPs were synthesized using Menthaarvensis (pudina) plant extract. The plant was washed with sterile distilled water. The plant extract was prepared by taking $25 \mathrm{~g}$ of thoroughly washed plant material in a $250 \mathrm{ml}$ Erlenmeyer flask with $100 \mathrm{ml}$ of distilled water, and then boiling the mixture for $10 \mathrm{~min}$ in a water bath. The leaf broth was cooled and filtered through Whatman No.1 filter paper (pore size $25 \mu \mathrm{m}$ ). For preparation of Co nanoparticles, $10 \mathrm{ml}$ of the prepared plant extract was added to $90 \mathrm{ml}$ of $1 \mathrm{mM}$ cobalt nitrate solution and incubated in a rotary shaker for $2 \mathrm{~h}$. The color of the solution changed from light yellow to brown indicating the formation of Co nanoparticles [31].

PMMA granules were obtained as commercial grade from Loxim Polymers, Jaipur) and used to prepare flat sheet membranes by the solution cast method. PMMA granules were weighed and dissolved in dichloromethane $\left(\mathrm{CH}_{2} \mathrm{Cl}_{2}\right)$ to prepare a $10 \%$ solution. The solution was stirred by a magnetic stirrer to ensure the uniform dissolution and to enhance the rate of dissolution at room temperature for about $5 \mathrm{~h}$. The $5 \%$ Co nanoparticles (of PMMA) were dispersed in the solvent dichloromethane using ultrasonicator. This dispersed solution was added to the PMMA solution and stirred for about $30 \mathrm{~min}$. The solution was put into flat-bottomed petri-dishes floating on mercury to ensure a uniform structure of membranes. The Solvent was allowed to evaporate slowly over a period of $10 \ldots 12 \mathrm{~h}$. The films so obtained were peeled off using forceps [32].

The plasma treatment device consisted of a source chamber with complete power supply, connected to a vacuum system. A magnet is positioned to get a magnetic field ( $0.5 \mathrm{~K}$ Gauss) inside the source chamber. Argon gas, used to generate plasma, was admitted into the source chamber using a flow controller and applying DC power between two electrodes. The confined plasma in the chamber was employed for surface modification. Applying a high voltage between two electrodes with magnetic field generated the DC glow discharge. The current in the upper and lower electrodes was maintained at few mA and $3.2 \mathrm{KeV}$. In this study Arplasma was used. The plasma was almost homogenous in a low-pressure glow discharge. The reaction chamber was evacuated and then refilled with low-pressure Ar gas to create glow discharge plasma. Plasma was energized by direct current. Other energetic species in plasma include radicals, electrons and meta-stable photons in short-wave UV range.

UV-Vis spectrum of NPs was taken using UV-Vis spectrophotometer SHIMADZU 1800. FTIR Analysis was done using FTIR spectrophotometer (IR Affinity-1 Shimadzu) in the range of $4000 \ldots 400 \mathrm{~cm}^{-1}$ for knowing the possible functional groups present with synthesized Co NPs. Scanning Electron Microscopic (SEM) analysis was done using Scanning electron microscope (Carl ZEISS EVOR-18) operated at $20 \mathrm{kV}$. 
Morphology and particle size of Co NPs were also determined using transmission electron microscopy (TEM) Technika TEM instrument operating at $200 \mathrm{kV}$.

Results and discussion. UV-Visible absorption spectrum shows the characteristic surface plasmon resonance (SPR) peak of Co NPs at $405 \mathrm{~nm}$ (Fig. 1), indicating reduction of cobalt nitrate formation of Co nanoparticles. Absorption bands obtained using FTIR were classified as (A) stretching vibration of Co NPs at $763 \mathrm{~cm}^{-1}$, (B) $\mathrm{C}=\mathrm{C}$ unsaturated at $1285 \mathrm{~cm}^{-1}$, (C) $\mathrm{C}=\mathrm{O}$ stretching vibration at $1722 \mathrm{~cm}^{-1}$, (D) $\mathrm{CH}_{3}$ stretching vibration at $3166 \mathrm{~cm}^{-1}$ and (E) C-H stretching vibration $3679 \mathrm{~cm}^{-1}$ of aromatic compounds (Fig. 2).

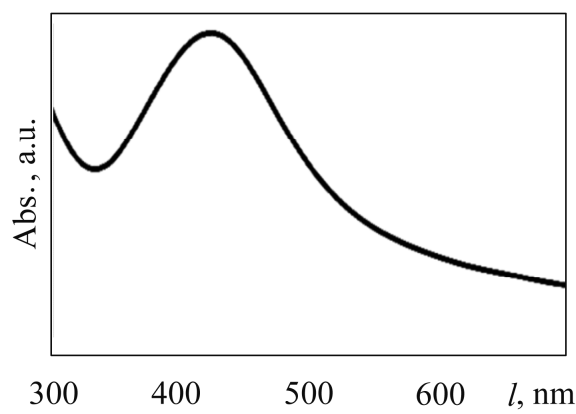

Fig. 1.

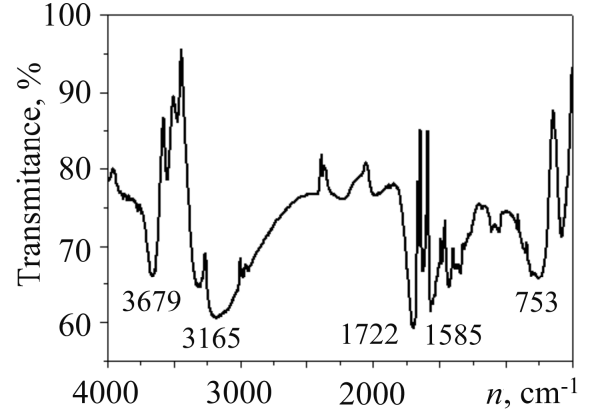

Fig. 2.

Fig. 1. UV-Vis absorption spectrum of Co NPs.

Fig. 2. FTIR spectra of vacuum dried Co NPs.

Co NPs were dispersed in acetone by ultra-sonication and used for particle size analysis (Fig. 3). Image clearly shows the spherical shape NPs with particle size ranging from $20 \ldots 28 \mathrm{~nm}$. Grain boundaries can be easily identified from TEM images showing no aggregations in Co NPs. Here for present study, TEM image was the best indicator of the particle size. But to determine aggregation present in NPs at higher sample amounts, we have also recorded SEM images of the synthesized Co NPs (Fig. 4). As individual Co NPs can easily be identified from the image, showing no aggregation in NPs even at higher sample amount. These Co NPs were used for synthesis of Nanocomposite Polymer Membranes, plasma treatment was done and characterized using different techniques [15].

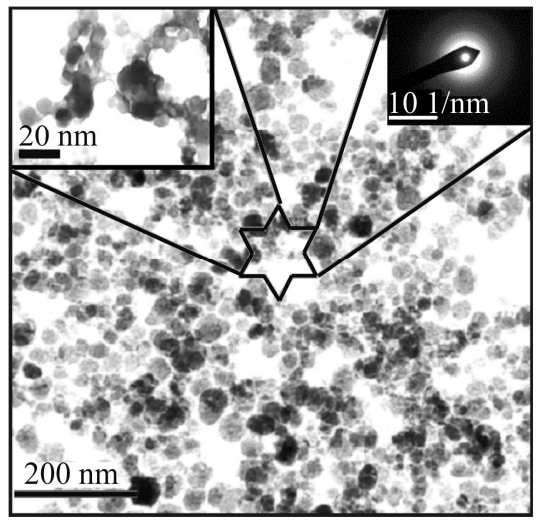

Fig. 3.

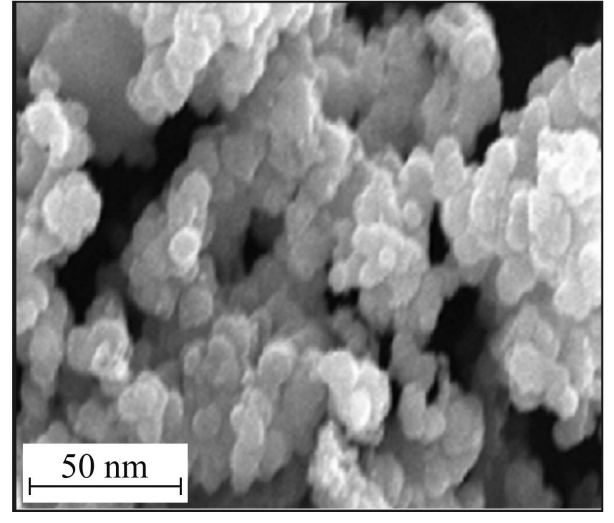

Fig. 4.

Fig. 3. TEM \& diffraction pattern of Co NPs.

Fig. 4. SEM image of Co NPs: EHT $=10.0 \mathrm{kV}$; WD $=12.0 \mathrm{~mm}$; signal $\mathrm{A}=\mathrm{SE} 1 ; \mathrm{Mag}=550.0 \mathrm{KX}$. 
FTIR spectra were obtained on FTIR spectrometer. FTIR was used to gather information about the chemical structure of a compound and chemical modification after plasma treatment. The FTIR images of the pristine and doped (untreated and plasma treated) membranes are as shown in Fig. 5. Certain characteristic differences are noticed at the peaks at certain wavelengths. These wavelengths were indicators of the change in the chemical bonding and structure of the samples due to plasma treatment.
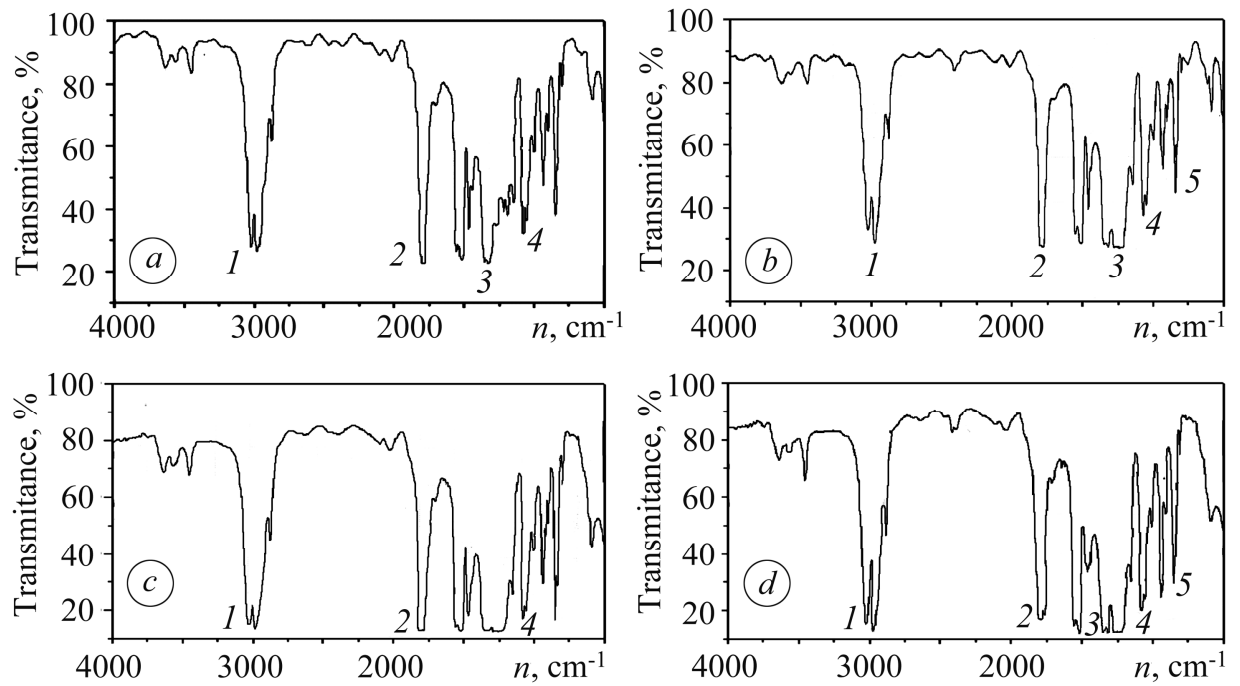

Fig. 5. FTIR spectra of pristine and Co nanocomposite polymer membrane both plasma treated and untreated: $a$ - pristine PMMA membrane; $b$ - Co nanocomposite PMMA membrane;

$c$-plasma treated pristine PMMA membrane; $d$ - plasma treated Co nanocomposite membrane. $\left(1-3100 \ldots 2850 \mathrm{~cm}^{-1}\right.$ characteristic of $\mathrm{CH}_{3} ; 2-\mathrm{C}=\mathrm{O}$ at $1770 \mathrm{~cm}^{-1} ; 3-1125 \ldots 1325 \mathrm{~cm}^{-1}$ characteristic of $\mathrm{C}-\mathrm{O}-\mathrm{C} ; 4-\mathrm{C}-\mathrm{O}$ at $1030 \mathrm{~cm}^{-1} ; 5-765 \mathrm{~cm}^{-1}$ Co NPs characteristic).
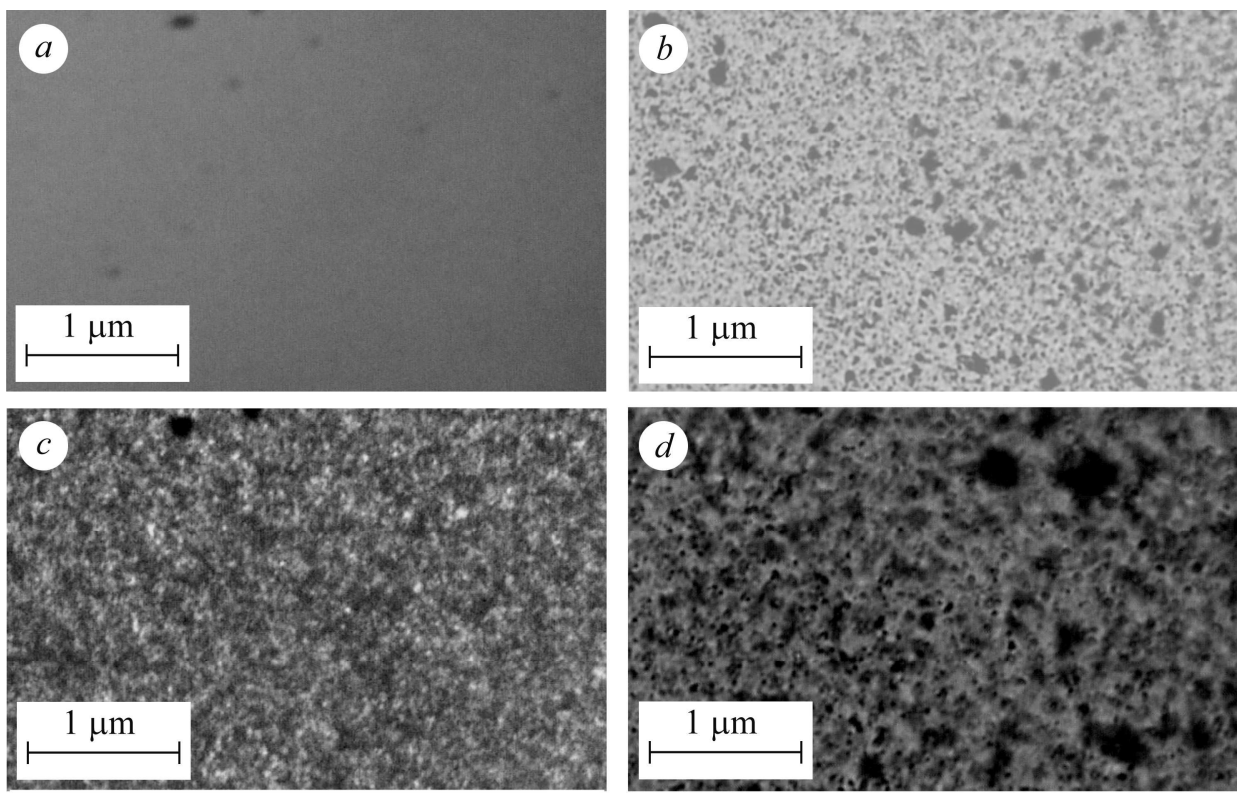

Fig. 6. SEM images of pristine and Co nanocomposite membrane both plasma treated and untreated $(\mathrm{EHT}=10.0 \mathrm{kV} ; \mathrm{WD}=12.0 \mathrm{~mm}$; Signal A $=\mathrm{SE} 1 ; \mathrm{Mag}=150.0 \mathrm{KX})$ : $a$-pristine membrane; $b-5 \%$ Co NPs Co nanocomposite membrane; $c$ - plasma treated pristine membrane; $d$-plasma treated $5 \%$ Co nanocomposite membrane. 
The peaks at about $3000 \ldots 2750 \mathrm{~cm}^{-1}$ were characteristic of- $\mathrm{CH}_{3}$ bonds. The similar peaks in the FTIR spectra of the treated and untreated samples showed that there was no change in the basic structure of nanocomposite membranes. The increments in the absorption bands of $\mathrm{C}-\mathrm{O}$ at $1030 \mathrm{~cm}^{-1}$ and $\mathrm{C}=\mathrm{O}$ at $1770 \mathrm{~cm}^{-1}$ were attributed to the creation of unsaturated $-\mathrm{C}=\mathrm{C}-$ bonds at $1645 \mathrm{~cm}^{-1}$ after plasma treatment. It was also observed from FTIR spectra that $\mathrm{C}-\mathrm{C}$ and $\mathrm{C}-\mathrm{H}$ bands decreased after plasma treatment. It indicated that the cross linking phenomenon enhanced during plasma treatment. The Co NPs showed its characteristic peak at $765 \mathrm{~cm}^{-1}$ for nanocomposite membrane.

We investigated surface morphologies of Co nanocomposite membrane using SEM. The SEM images of nanocomposite membrane are shown in Fig. 6. Scanning Electron Microscopic (SEM) analysis was done using Scanning electron microscope (Carl ZEISS EVOR-18) operated at $20 \mathrm{kV}$. Plasma treated nanocomposite membrane can be compared with untreated one which shows the improvement in porosity and roughness.

\section{CONCLUSIONS}

Color of solution changed from green to brownish as plant extract was mixed in the aqueous solution of the cobalt ion complex, thus giving the primary indication of Cobalt nanoparticles formation, which was further confirmed by analyzing these NPs by different techniquei like UV-Vis spectrophotometer, FTIR, TEM and SEM.

The UV-Visible spectrum was obtained in a visible range of 300 to $800 \mathrm{~nm}$. A typical absorbance peak at $405 \mathrm{~nm}$ of cobalt nanoparticles was obtained due to the surface Plasmon vibrations of cobalt nanoparticles. Particle size of biosynthesized cobalt nanoparticles was further confirmed by TEM and SEM measurements which were about $20 \ldots 28 \mathrm{~nm}$. The FTIR measurement was carried out to identify the possible interaction between biomolecule and CoNPs. The FTIR measurements of biosynthesized cobalt nanoparticles showed the bands of about $763 ; 1605 ; 1722 ; 3165$ and $3679 \mathrm{~cm}^{-1}$.

The pristine PMMA membranes and Co nanocompositemembrane (5 weight\%) were prepared by the solution cast method. The Ar plasma treatment technique applied here showed considerable improvement in the chemical and surface properties of membranes. Plasma treatment helped in increasing the flux whereas doping modified the surface properties. The SEM images showed high porosity and roughness after plasma treatment. As nanocomposite membranes were prepared without help of any support, it could be concluded that PMMA had considerable strength as compared to other polymeric materials like polyamide which could not be prepared without the help of support. The increments in the absorption bands of $\mathrm{C}-\mathrm{O}$ at $1030 \mathrm{~cm}^{-1}$ and $\mathrm{C}=\mathrm{O}$ at $1770 \mathrm{~cm}^{-1}$ were attributed to the creation of unsaturated $-\mathrm{C}=\mathrm{C}-$ bonds at $1645 \mathrm{~cm}^{-1}$ after plasma treatment, while decrease in intensity of $\mathrm{C}-\mathrm{C}$ and $\mathrm{C}-\mathrm{H}$ bands indicated that cross linking phenomenon enhanced after plasma treatment.

РЕЗЮМЕ. Досліджено вплив іонно-плазмової обробки на властивості мембрани 3 нанокомпозитного полімеру. Наночастинки кобальту одержано хімічним синтезом. Мембрани завтовшки $20 \mu \mathrm{m}$ виготовлено нанесенням нанокомпозитного полімеру з розчину 3 подальшою іонно-плазмовою обробкою. Мембрани вивчено перед та після їх обробки плазмою методами оптичної мікроскопії, сканівної електронної мікроскопії та інфрачервоної Фур'є-спектроскопії. Виявлено, що іонно-плазмова обробка - ефективний засіб поліпшення поверхневих та хімічних властивостей мембран з нанокомпозитних матеріалів.

РЕЗЮМЕ. Исследовано влияние ионно-плазменной обработки на свойства мембраны из нанокомпозитного полимера. Наночастицы кобальта получены химическим синтезом. Мембраны толщиной $20 \mu \mathrm{m}$ изготовлены нанесением нанокомпозитного полимера с раствора с последующей ионно-плазменной обработкой. Мембраны изучены до и после обработки плазмой методами оптической микроскопии, сканирующей электронной микроскопии и инфракрасной Фурье-спектроскопии. Выявлено, что ионно-плазменная обра- 
ботка - эффективное средство улучшения поверхностных и химических свойств мембран с нанокомпозитных материалов.

Acknowledgments. The authors wish to thanks and acknowledge Ms. Priti Agarwal for helping in synthesis of Co nanoparticles. Authors are also thankful to Dr. B. L. Choudary of Department of Physics, University of Rajasthan for SEM analysis and Jawaharlal Nehru Memorial Fund, New Delhi, India for providing Scholarship to Mr. Narendra Kumar Agrawal to carry out his Ph. D work.

1. Mohammadia M. R., Fray D. J., and Cordero-cabrera M. C. Sensor performance of nanostructured $\mathrm{TiO}_{2}$ thin films derived from particulate sol-gel route and polymeric fugitive agents // Sensors and Actuators B. - 2007. - 124. - P. 74-82.

2. Surface modification of thin-film composite polyamide reverse osmosis membranes with thermo-responsive polymer (TRP) for improved fouling resistance and cleaning efficiency / Y. Sanchuan, L. Xuesong, L. Jingqun et al. // Separa. \& Purification Technol. - 2011. - 76. - P. 283-289.

3. Agarwal R., Agrawal N. K. and Singh R. Low temperature annealing of cadmium sulphide thin films for improving surface-interface properties // Materials Focus. - 2014. - 3, № 3. - P. 267-271.

4. Yang S., Jiang $P$., and Tang J. Association of miR-502-binding site single nucleotide polymorphism of SET8 gene with non-small cell lung cancer risk in chinese people // J. Bionanosci. - 2013. - 7. - P. 585-589.

5. Mesoporous silica films as a novel biomaterial: applications in the middle ear / N. Ehlert, P. P. Mueller, M. Stieve et al. // Chem. Soc. Rev. - 2013. - 42. - P. 3847-3861.

6. Fabrication of a flexible UV band-pass filter using surface plasmon metal-polymer nanocomposite films for promising laser applications / G. Kedawat, B. K. Gupta, P. Kumar et al. // ACS Applied Materials \& Interfaces. - 2014. - 6, № 11. - P. 8407-8414.

7. Surface treatment of CoS/polymer nanocomposite membranes for improving wettability and surface energy / N. K. Agrawal, R. Agarwal, Y. K. Vijay, and K. C. Swami // J. Mat. Sci. and Surf. Eng. - 2014. - 1, № 3. - P. 82-87.

8. Effect of different disinfectants on the microhardness and roughness of acrylic resins for ocular prosthesis / A. Moreno, M. C. Goiato, D. M. D. Santos et al. // Gerodontology. - 2013. - 30. - P. 32-39.

9. Surface modification of nano composite polymer membranes by ion plasma irradiation for improving biocompatibility of polymers / N. K. Agrawal, R. Agarwal, K. Awasthi et al. // Adv. Mat. Letters. - 2014. - 5, № 11. - P. 645-651.

10. The application of poly(3-hydroxybutyrate-co-3-hydroxyhexanoate) scaffolds for tendon repair in the rat model / W. R. Webb, T. P. Dale, A. J. Lomas et al. // Biomaterials. - 2013. - 34. - P. 6683-6694.

11. Synthesis and characterization of plasma treated tio ${ }_{2}$ nano composites polymer membranes / N. K Agrawal., K. Awasthi, Y. K. Vijay, and K. C. Swami // Adv. Electrochem. - 2013. - 1, № 2. - P. 98-104.

12. Bagra B., Pimpliskar P., and Agrawal N. K. Bio-compatibility, surface \& chemical characterization of glow discharge plasma modified $\mathrm{ZnO}$ nanocomposite polycarbonate // AIP Conf. Proc. - 2014. - 1591. - P. 189-191.

13. Characterization of $\mathrm{N}_{2}$ Plasma treated nanocomposites polymer membranes / N. K., Agrawal R. Agarwal, Y. K. Vijay, and K. C. Swami // J. Mat. Sci. and Surf. Eng. - 2013. - 1, № 1. - P. 4-7.

14. Regan $O$. B. and Gratzel M. A low-cost, high-efficiency solar cell based on dye-sensitized colloidal $\mathrm{TiO}_{2}$ films // Nature. - 1991. - 353. - P. 737-742.

15. Goel S. and Mathew S. K. Automated Detection, characterization, and tracking of sunspots from SoHO/MDI continuum images // Solar Phys. - 2014. - 289. - P. 1413-1431.

16. Synthesis and characterization of colloidal $\mathrm{TiO}_{2}$ nanoparticles: through titanium chloride rich solutions / N. K. Agrawal, M. Singh, Y. K. Vijay, and K. C. Swami // Adv. Sci. Eng. Med. - 2014. - 6, № 5. - P. 595-602.

17. Decolorization of aqueous solution containing organic synthetic-dye via dark-catalysis process using hydrothermally synthesized semiconductor-oxides nanotubes / R. Rao, R. Sukla, P. K. Sahoo, and H. S. Panda // Ibid. - 2014. - 6. - P. 173-183. 
18. Surface modification of Ag nanocomposite polymer membranes by glow discharge plasma / N. K. Agrawal, R. Agarwal, Y. K. Vijay, and K. C. Swami // J. Mat. Sci. and Surf. Eng. - 2013. - 1, № 1. - P. 23-27.

19. Formation of nanosize $\mathrm{Ag}-\mathrm{TiO}_{2}$ composite by Sol-Gel method and investigation of band gap decline / M., Hatami K. V. Rao, M. Ahmadipour, and V. Rajendar // Adv. Sci. Eng. Med. - 2013. - 5. - P. 1039-1045.

20. Reactive polymer surfaces for cell colonization / N. K. Agrawal, R. Agarwal, Y. K. Vijay, and K. C. Swami // J. Mat. Sci. and Surf. Eng. - 2014. - 1, № 2. - P. 32-35.

21. Characterization of antiplatelet property of silver nanoparticle / S. Shrivastava, T. Bera, S. K. Singh et al. // ACS Nano. - 2009. - 116. - P. 15-23.

22. Enhancement of sterilization efficiency of polymer nanocomposite by argon plasma irradiation / N. K. Agrawal, R. Agarwal, Y. K. Vijay, and K. C. Swami // J. Bionanoscience. - 2014. - 8, № 2. - P. 108-115.

23. $\mathrm{PC}$ - $\mathrm{ZnO}$ nanocomposites as efficient and reusable catalyst for the synthesis of $\alpha, \beta$-unsaturated compounds and aldimines / A. Dandia, V. Parewa, S. L. Gupta et al. // Current Organic Chemistry. - 2014. - 18, № 20. - P. 2652-2664.

24. ZnO nanocomposites polystyrene membranes: plasma treatment \& characterization / N. K. Agrawal, R. Agarwal, S. Khandelwal et al. // Int. J. Eng. Research \& Technol. - 2014. - 1. - P. 104-107.

25. Plasma etching technology for surface and chemical modifications of aluminium and Poly Methyl Meth Acrylate (PMMA) nanocomposites / N. K. Agrawal, R. Agarwal, Y. K. Vijay, and K. C. Swami // Adv. Sci. Eng. Med. - 2014. - 6, № 6. - P. 698-703.

26. Impact of manufacture technique on seawater desalination performance of thin-film composite polyamide-urethane reverse osmosis membranes and their spiral-wound elements / L. Meihong, Y. Sanchuan, Q. Ming et al. // J. Mem. Sci. - 2012. - 348. - P. 268-275.

27. Agrawal N. K. Study of enhancement in bio-adoptability \& biocompatibility of nanocomposite polymer membranes by plasma treatment. - India: Jaipur; Malaviya Nation. Inst. Technol. - Ph. D. Thesis, 2014.

28. Oehr C. Plasma surface modification of polymers for biomedical use // Nucl. Instr. and Meth. in Phys. Res. - 2003. - B 40. - 208.

29. Synthesis of Al \& Ag nanoparticles through ultra-sonic dissociation of thermal evaporation deposited thin films for promising clinical applications as polymer nanocomposite / N. K. Agrawal, R. Agarwal, D. Bhatia et al. // Adv. Mat. Letters. - 2015. - 6, № 2. - P. 98-105.

30. Kohma T., Oyamatsu D., and Kuwabata S. Preparation of selective micro glucose sensor without permselective membrane by electrochemical deposition of ruthenium and glucose oxidase // Electrochemistry Comm. - 2007. - 9. - P. 1012-1024.

31. Agarwal R., Agrawal N. K., and Singh R. Cicerarietinum leaf extract mediated synthesis of silver nanoparticles and screening of its antimicrobial activity // Adv. Sci. Eng. Med. - 2014. - 6, № 2. - P. 203-207.

32. Green synthesis of silver nanoparticles and their activity against mycobacterium tuberculosis / P. Agarwal, A. Mehta, S. Kachhwaha, and S. L Kothari. // Ibid. - 2013. - 5, № 7. - P. 709-714.

Received 23.04.2014 